\title{
高温加熱処理に伴う豚肉および牛肉の脂質成分の変化
}

\author{
江 琦* ・大島敏 明**. 和田 俊 ${ }^{* *}$ ・小泉千秋**
}

\section{Changes in the Lipids of Pork and Beef during Heat Treatment at High Temperature}

\author{
Qi JianG*, Toshiaki OhShima**, Shun WadA**, and Chiaki Korzumi ${ }^{* *}$ \\ * Beijing Food Industry Research Institute, 54 Yongdingmenwai Anlelinlu Beijing, China \\ ** Department of food Science and Technology, Tokyo University of Fisheries, \\ 4-5-7 Konan, Minato-ku, Tokyo 108
}

\begin{abstract}
Changes in the lipids of pork and beef, sliced and ground, were studied during heat treatment at higher temperature. Fat portions of the samples were trimmed, then they were sliced about 8 $\mathrm{mm}$ in thickness, vacuum-packed in flexible retort pouches $(13 \times 17 \mathrm{~cm})$, and cooked to a core temperature of $124^{\circ} \mathrm{C}$ at the $\mathrm{F}$ values ranging from 4.6 to 32 . Finely ground pork and beef were also cooked in the same manner. TBA value of pork increased during the heat treatment and was higher in the ground meat than in the sliced one. However, there was no relationship between the degree of increase in TBA value and the increase of $F$ value. Contrary, TBA value of beef decreased during the heat treatment. The contents of total lipids (TL) in pork and beef were $3 \sim 4 \%$ and $8 \sim 10 \%$, respectively, and almost unchanged during the heat treatment, while those of polar lipid (PL) slightly increased. In the PL of pork and beef lysophosphatidylcholine (LPC) and lysophosphatidylethanolamine (LPE) were formed during the heat treatment and increased with the increasing of $F$ value. LPC and LPE were found at higher levels in beef than pork. Free fatty acid (FFA) both in pork and beef decreased during the heat treatment, though some of PC and PE were hydrolysed to LPC and LPE, respectively. No outstanding change was found on triglyceride (TG) composition on the basis of total carbon number of acyl chain during the heat treatment at the $F$ values of less than 8.6 for pork and 12 for beef. However, when the samples were cooked at the $\mathrm{F}$ values of 21 or higher, TG of C-52 and C-54 decreased, while those of $\mathrm{C}-48$ and $\mathrm{C}-50$ increased. This observation suggests that intra-and/or inter-molecular rearrangement of TG occurs during the heat treatment. Little change was observed in the fatty acid compositions of TL, PL, and non-polar lipid (NL) in pork and beef during the heat treatment, with the exception of $\mathrm{C}_{20: 4}$ in $\mathrm{PE}$ which decreased.
\end{abstract}

(Received Sep. 29, 1984)

豚肉, 牛肉, 舀肉などの食肉は，加熱処理してから泠 藏すると,これらの生鮮肉を冷藏したときとは異なった 酸敗臭を笔生することはよく知られている。この酸化臭 は, “warmed-over flavor”を呼ばれ，その原因に脂 質の酸化が関与しているものと考えられ，加熱食肉の脂 質酸化については多くの研究が行われてきだ2)。

しかしながら、レトルトパウチ食品のよらに真空包歳 して高温加熱処理をした食品中で起こる脂質成分の变化
については汪とんど知られていない。レトルトパゥチ食 品は，缕九た包装材料の開発と高温加熱处理技術の発展 に上り，すでに多くの食品について商業的規模で生産さ れ, 今後さらに食品の種類, 生座量共に增加するものと 思われる。

本研究では，豚肉, 牛肉などを素材とした優れたレトル トパウチ食品を開発するための基碟資料を得る目的で， これらの食肉を高温加熱処理したときの脂質成分の変化

\footnotetext{
* 北京市食品工業研究所（中国北京市永定門外安楽林路 54 号）

** 東京水産大学食品生産化学料（广 108 東京都港区港南 4-5-7)
} 
について検討した。

\section{実 験 方 法}

\section{1. 試料の調製}

食肉小売店から豚の肩肉衿よび牛の腿肉を購入し供試 した。脂肪部を除去した肉塊を二等分に切断し，一方は 切身肉用，残りは挽き肉用とした。切身肉は厚さ䄪 8 $\mathrm{mm}$, 重量 $80 \sim 100 \mathrm{~g}$ になるように切り, 一方挽き肉は $0.45 \mathrm{~cm}$ 目のプレートの肉挽き器に 2 回通して調製し た。いずれも， $13 \times 17 \mathrm{~cm}$ のレトルトパウチ（東洋製尔 製 hiRP-F) に詰め, 真空度 $500 \mathrm{mmHg}$ で真空包装し た。なお，挽き肉の場合には肉の厚さが 8〜10 mmにな るよらに圧してできるだけ均一になるようにした。

高温加熱処理には，加熱殺菌冷却装居（東洋製午製 H60-C50-120/150-SWR-SA) を用い，試料の中心温度 を $124^{\circ} \mathrm{C}$ に設定して F 值 4.6〜32 の籁围で加熱殺菌 した。本研究の目的は, 高温加熱処理に伴う脂質の変化 を調べることにあるので，極端に高いF值も試験すると 共に，加熱処理後は值ちに冷却して，分析に供するまで $-20^{\circ} \mathrm{C}$ に凍結眝蔵した。

\section{2. 脂質の抽出と分画}

レトルトパウチを開封後, 切身肉は肉挨き器で推き肉 とし，これに加熱時に分離した液汁を加えて，BLIGH \&

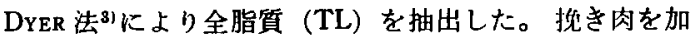
熱した試料は，乳鉢中で夜汁と混合し，同様にして TL を抽出した。

TL は，以下の条件 ()で極性脂質区 (PL) と非極性脂 質区（NL）とに分画した。カラム，Bio-beads S-X2, $2.6 \times 70 \mathrm{~cm}$; 溶離液, ペンゼン; 流速, $70 \mathrm{~m} l / \mathrm{h}$ 。

\section{3. 脂質組成の分析}

PL および NL は, ケイ酸溥層クロマトグラフィー (TLC, Merck 社製, シリカゲル $0.25 \mathrm{~mm}$; 活性化, $\left.110^{\circ} \mathrm{C} ， 1 \mathrm{~h}\right)$ で脂質組成を分析した。展開斉は，PL に は $\mathrm{CHCl}_{8} / \mathrm{MeOH} / \mathrm{AcOH} / \mathrm{H}_{2} \mathrm{O}$ (25:15:4:1, v/v) をまた NLには石油ェーテル/ェーテル $/ \mathrm{AcOH}(82$ $: 18: 1, \mathrm{v} / \mathrm{v})$ を用いた。展開後，50\% 硫酸を唄霧して $130^{\circ} \mathrm{C}, 20 \mathrm{~min}$ 間加熱炭化後, デンシトメトリー（島津 社製，クロマトスキャナーCS-920) で分析した。成分 の同定は，標準品の $\mathrm{R}_{\mathrm{f}}$ との照合によった。なお，各 脂質クラス量は，デンシトィトリーで得られた組成比と $\mathrm{PL}$ 怙よひ NLの含量から算出 $\mathrm{L}$ ，肉 $100 \mathrm{~g}$ 中の $\mathrm{g}$ たは mgとして表わした。

4. PL の高速液体クロマトグラフィー

高速液体クロマトグラフィー (HPLC, 日本分光社製,
FLC A 700) にかけて, PL を phosphatidylethanolamine (PE), lysophosphatidylethanolamine (LPE), phosphatidylcholine (PC), sphingomyelin (SPM) および lysophosphatidylcholine (LPC) に分離した。 分析条件は次のようである。カラム, Partisil-10 SCX (Whatman 社製, $9.0 \mathrm{~mm} \times 25 \mathrm{~cm}$ ); 溶離液, $\mathrm{CH}_{8} \mathrm{CN} /$ $\mathrm{MeOH} / \mathrm{H}_{2} \mathrm{O}(60: 30: 7 \mathrm{v} / \mathrm{v})$, 流速, $4.8 \mathrm{~m} l / \mathrm{min}_{\mathrm{o}}$ 分 取した PE および PCについて脂肪酸組成を測定した。 なお， PL の HPLCパターンを見る場合には，小型カ ラム $(4.8 \mathrm{~mm} \times 25 \mathrm{~cm})$ を用いた。溶離液は，同じ組成 の混合溶媒で流速 $1.6 \mathrm{ml} / \mathrm{min} て ゙$ 流した。

\section{5. 脂肪酸組成の分析}

TL，PL， NL，PCおよび PE はそれぞれ 1N KOH -EtOH でヶン化し，不ヶン化物を除去したのち，14\% $\mathrm{BF}_{8}-\mathrm{MeOH}$ (Applied Science 社製) を用いて脂肪酸の メチルエステルを調製した。ただし，PE については， 妨害物質を除くためにヶン化後の混合脂肪酸を NL と同 一の条件下で TLCにかけ，脂肪酸部分を搔き取って抽 出し，チルエステル化した。脂肪酸の愉出には 0.02 \% 2,7-dichlorofluorescein の EtOH 溶液を用いた。 また，NL中に含まれる遊離脂肪酸（FFA）も同様にし て TLC 板から掻き取ってィチェステル化した。ガスク ロマトグラフィー(GLC) 0条件は以下のと扣りである。 ガスクロマトグラフ, 島津 GC-6APF; 検出器, FID; カラム, 20\% DEGS (Gas Chrom P, AW, DMCS 処 理, $80 \sim 100$ ^ッシュ)， $3 \mathrm{~mm} \times 2 \mathrm{~m}$ ガラスカラム; カ ラム温度, $195^{\circ} \mathrm{C}$; 試料気化室温度, $250^{\circ} \mathrm{C}$; キャリアカ ᄌ, $\mathrm{N}_{2}, 20 \mathrm{ml} / \mathrm{min}$

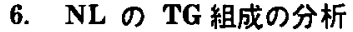

NL $の$ acyl chain の炭素数に 基づく triglyceride (TG) 組成の分析を次の GLC 条件で行った。ガスクロ マトグラフ, 島津 GC-4BM; 検出器, FID; カラム, 1 \% JXR (Gas Chrom Q, 60 80メッシュ)，カラム温 度, $245 \sim 340^{\circ} \mathrm{C}, 2^{\circ} \mathrm{C} / \mathrm{min}$ 昇温; 試料気化室温度, 350

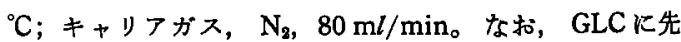
立って試料はすべて白金黒を触媒として水素添加した。 また，各 TGのピーク面積は，標準品を用いて面積補正 をした。

\section{TBA 值の測定}

SINNHUBER らの方法可に従い，絬果は mg malonaldehyde/kg 肉として表わした。 


\section{結果および考察}

1. 加熱に伴う水分, TBA 值および脂質含量の变化 供試豚肉扣よび牛肉の水分は, Table 1 に示すよらに それぞれ 74〜76\%および 66〜69\% で，加熱処理して あほとんど変化しなかった。これは，試料を水蒸気非透 過性のレトルトパウチに真空包装して加熱したこと扰 び加熱により肉から遊離した液汁を分析に際して加熱肉 に加えたことによるるのと思われる。 生鲜肉の TBA 值は, 挽き肉, 切身肉ともに牛肉より 豚肉で高かった。加熱により誐肉の TBA 值はさらに上 昇したが，その程度は切身肉より挽き肉で著しかった。 しかし，F值が高くなるほど TBA 值が上昇する傾向は 認められなかった。真空包装とはいえ袋内または肉組織 内に僅かに残存した空気により脂質が酸化したために， TBA 值が上昇したものと思われる。一方, 牛肉の場合
には加熱により TBA 值は低下した。牛肉の場合にも袋 内の残存空気により豚肉の場合と同様に脂質酸化が当然 起こるものと予想されるが，後述するように TL の脂 肪酸組成は腺肉に比べて polyene 酸の 組成比が低く, そのため生成する malonaldehyde (MA) 量が少なかっ たこと怙よび一旦生成した MA の一部が熱分解あるい は肉成分と反応して減少し，その城少量が生成量を上迴 ったためと推測される。

供試豚肉技よび牛肉の TL 含量は，それぞれ $3 \sim 5 \%$ および8〜11\%で牛肉で高かった。しかし，いずれの試 料も PL 含量は $0.6 \sim 0.8 \%$ で肉の種類に関俰なく汇 同様であった。したがって，牛肉で TL 含量が高いのは NL 含量が高いためである。

肉の脂質含量は，加熱しても目立った変化は示さなか ったが，PL 含量にやや増加䝨向が認められた。加熱処 理による肉質の変化が PL の抽出性に影響を与えたため

Table 1 Changes in moisture contents, TBA values and lipid contents of pork and beef during heat treatments at various $\mathrm{F}$ values $\left(124^{\circ} \mathrm{C}\right)$

\begin{tabular}{|c|c|c|c|c|c|c|}
\hline \multirow{2}{*}{ Sample } & \multirow{2}{*}{$\begin{array}{l}\text { Heat treatment } \\
\quad(\mathbf{F} \text { value })\end{array}$} & \multirow{2}{*}{$\begin{array}{l}\text { Moisture } \\
(\%)\end{array}$} & \multirow{2}{*}{ TBA value*1 } & \multicolumn{3}{|c|}{ Lipid content (\%) } \\
\hline & & & & TL*2 & $\mathrm{PL} * \mathrm{~s}$ & $\mathrm{NL} * 4$ \\
\hline \multirow[t]{4}{*}{ Pork (Ground) } & $\mathrm{R}^{* 5}$ & 75.7 & 1.02 & 3.03 & 0.69 & 2.34 \\
\hline & 8.6 & 75.2 & 3.28 & 2.94 & 0.66 & 2.28 \\
\hline & 12 & 75.0 & 3.10 & 3.08 & 0.70 & 2.38 \\
\hline & 21 & 74.0 & 2.83 & 3.21 & 0.70 & 2.51 \\
\hline \multirow[t]{5}{*}{ Pork (Slice) } & $\mathbf{R} * 5$ & 74.6 & 0.06 & 4. 28 & 0.67 & 3.61 \\
\hline & 4.6 & 75.6 & 1.52 & 2.13 & 0.72 & 1.41 \\
\hline & 7.9 & 74.7 & 1.35 & 4.62 & 0.63 & 3.99 \\
\hline & 21 & 74.7 & - & 3.06 & 0.67 & 2.39 \\
\hline & 32 & 75.5 & 1.61 & 4.22 & 0.73 & 3.49 \\
\hline \multirow[t]{4}{*}{ Beef (Ground) } & $R^{* 5}$ & 67.8 & 2.77 & 8.11 & 0.61 & 7.50 \\
\hline & 8.6 & 68.2 & 1.75 & 8.55 & 0.72 & 7.82 \\
\hline & 12 & 68.6 & 1.82 & 7.87 & 0.74 & 7.13 \\
\hline & 21 & 67.2 & 1.41 & 8.57 & 0.70 & 7.87 \\
\hline \multirow[t]{5}{*}{ Beef (Slice) } & $R^{* 5}$ & 66.0 & 1.99 & 9.93 & 0.56 & 9.37 \\
\hline & 4.6 & 66.8 & 0.46 & 9.94 & 0.69 & 9.25 \\
\hline & 7.9 & 66.7 & 0.85 & 9.63 & 0.74 & 8.89 \\
\hline & 21 & 66.4 & 0.81 & 8.27 & 0.71 & 7.56 \\
\hline & 32 & 67.8 & 0.87 & 11.19 & 0.77 & 10.42 \\
\hline
\end{tabular}

*1 : mg malonaldehyde/kg sample

*2 : Total lipid

*8 : Polar lipid fraction

*4 : Non-polar lipid fraction

*5 : Prior to cooking 
であろら。

\section{2. 加熱に伴う PL の脂質クラスの变化}

豚肉, 牛肉の PL は, Table 2 に示すように, LPC, SPM, PC, LPE, phosphatidylserine (PS) および PE から成る。加熱により，いずれの試料でも LPC および LPE が增加し，それらの増加量は F 值が高くなるほど 多かった。KELLER ら6) 無包装ではあるが，ハンバーグ 用の肉を $60 \sim 70^{\circ} \mathrm{C}$ に加熱したとき LPC および LPE の生成と PC おょび PE の減少を認めている。本来 LPC や LPE は PC P PE の加水分解により生成するおの であるから，LPCゃ LPE の増加は PC や PE の減少 をもたらすのが普通である。しかし，本研究では PC お よび PEの減少は認められなかった。前述した加熱によ る PL の抽出量の増加と関係があるように思われる。

PL からリゾ型リン脂質が生成する機構は，酳素的加 水分解加加熱に上る 加水分解によるためであるう。一 般に，LPC や LPE は PC および PE に phospholipase $A_{2}$ が作用して生成するものである。したがって， レトルト中での加熱に際し試料の肉温が徐々に上昇する 間に phospholipase $A_{2}$ が作用したとも考えられる。し

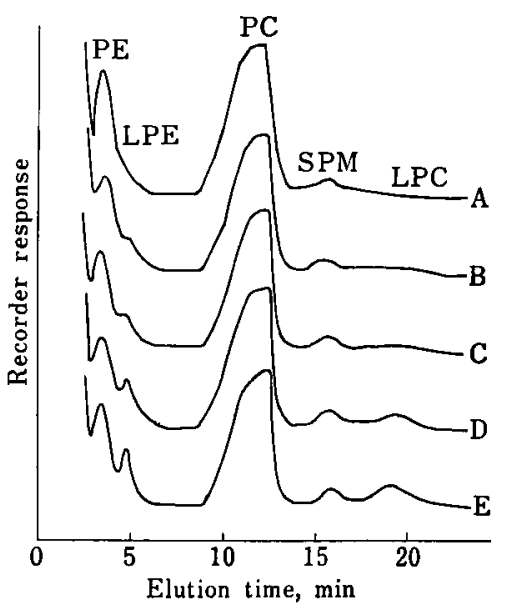

Fig. 1 Changes in high performance liquid chromatograms of polar lipid in beef during heat treatments at various $F$ values $\left(124^{\circ} \mathrm{C}\right)$. $\mathrm{F}$ value: $\mathrm{A}$, Prior to cooking; B, 4.6; C, 7.9; D, 21; E, 32 . Abbreviations used in the figure are the same in foot-note of Table 2.

Table 2 Changes in lipid class contents of polar lipid fractions in pork and beef during heat treatments at various $\mathrm{F}$ values $\left(124^{\circ} \mathrm{C}\right)$

\begin{tabular}{|c|c|c|c|c|c|c|c|c|}
\hline \multirow{2}{*}{ Sample } & \multirow{2}{*}{$\begin{array}{l}\text { Heat treatment } \\
\text { (F value) }\end{array}$} & \multicolumn{7}{|c|}{ Lipid class $(\mathrm{mg} / 100 \mathrm{~g})^{* 1}$} \\
\hline & & LPC & SPM & $\mathrm{PC}$ & LPE & PS & $\mathrm{PE}$ & UK \\
\hline \multirow[t]{4}{*}{ Pork (Ground) } & $\mathrm{R}^{* 2}$ & 3.8 & 39.1 & 307.1 & - & 76.0 & 201.7 & 61.9 \\
\hline & 8. 6 & 8.3 & 28.2 & 291.0 & 6.1 & 52.7 & 195.9 & 78.0 \\
\hline & 12 & 9.2 & 32.8 & 275.4 & 7.6 & 69.3 & 222.6 & 83.3 \\
\hline & 21 & 14.1 & 32.9 & 317.9 & 14.3 & 60.1 & 198.8 & 62.0 \\
\hline \multirow[t]{5}{*}{ Pork (Slice) } & $\mathrm{R} * 2$ & 5.0 & 27.6 & 260.0 & - & 65.9 & 227.7 & 84.0 \\
\hline & 4.6 & 9.7 & 29.0 & 303.4 & 8.2 & 59.6 & 220.5 & 89.6 \\
\hline & 7.9 & 5.7 & 24.1 & 257.1 & 6.6 & 58.6 & 211.7 & 66.2 \\
\hline & 21 & 12.4 & 29.1 & 288.8 & 12.9 & 62.1 & 199.3 & 65.5 \\
\hline & 32 & 18.8 & 41.3 & 319.4 & 29.9 & 75.3 & 182.9 & 62.2 \\
\hline \multirow[t]{4}{*}{ Beef (Ground) } & $\mathrm{R}^{* 2}$ & 16.9 & 34.9 & 292.7 & - & 46.5 & 165.4 & 54.4 \\
\hline & 8.6 & 30.5 & 38.7 & 333.6 & 9.8 & 66.2 & 175.7 & 65.4 \\
\hline & 12 & 39.9 & 41.8 & 328.4 & 14.5 & 62.2 & 173.3 & 79.9 \\
\hline & 21 & 51.3 & 37.6 & 280.1 & 35.3 & 69.5 & 150.4 & 76.1 \\
\hline \multirow[t]{5}{*}{ Beef (Slice) } & $\mathbf{R} * 2$ & 10.1 & 39.0 & 283.2 & - & 34.9 & 159.7 & 33.1 \\
\hline & 4.6 & 29.7 & 33.3 & 296.0 & 21.0 & 64.2 & 182.5 & 60.0 \\
\hline & 7.9 & 23. 6 & 34.3 & 325.8 & 11.3 & 72.3 & 208.6 & 64.1 \\
\hline & 21 & 51.3 & 40.3 & 295.8 & 29.0 & 69.2 & 157.8 & 66.9 \\
\hline & 32 & 79.5 & 56.5 & 337.0 & 47.5 & 76.0 & 129.7 & 44.1 \\
\hline
\end{tabular}

*1 : LPC; lysophosphatidylcholine, SPM; sphingomyelin, PC; phosphatidylcholine, LPE; lysophos phatidylethanolamine, PS; phosphatidylserine, PE; phosphatidylethanolamine, UK; unidentified

*2 Prior to cooking 
かし，F値が高くなるほどリゾ型リン脂質の生成量が増 加していること，および phospholipase $\mathrm{A}_{2}$ の耐熱性を 考虑すると，加熱による加水分解が関与している可能性 むある。このほか， SPM 拈よび PS 含量には，加熱に よる一定の变化は認められなかった。

なお，LPC および LPE の生成量は，豚肉より牛肉 で多かった。そこで，牛肉の PL の加熱による HPLC クロマトグラムの変化を Fig. 1 に示す。 LPC 扰び LPE の生成が明瞭である。

\section{3. 加熱に伴う NL の脂質クラスの变化}

供試豚肉および牛肉の NL の脂質クラスは, Table 3 に示すよ5に共に少量の 1,2-diglyceride (1,2-DG) と cholesterol (ST)，FFA および TG から成り，1,2DG および TG 含量は原肉より牛肉で高かった。加熱処 理により豚肉，牛肉共に 1,2-DG および FFA 含量が 减少した。1,2-DG が加熱により僅かではあるが减少し たのは, lipase による TG の加水分解によるか，ある いは熱分解によるものと思わ机るが，もし加水分解によ
るものとすれば，FFA は增加する筈である。また，前 述したよらに, 加熱により LPCゃ LPE は増加したが， この場合にも $\mathrm{PC}$ および PE から遊離した脂肪酸のた めに, 全体として FFA は增加する䇢である。しかし， 実際には Table 3 に示すようにいずれの試料でも増加 せずに隇少傾向を示した。その理由は明らかでないが， FFA の加熱による酸化分解あるいは肉中の他の成分と の反応などが考えられる。 なお，STおよび TG 含量は加熱しても一定の变化を 示さなかった。また，一般にいわれているよらな TGの 加熱による加水分解も認められなかった。

\section{4. 加熱に伴う NL の TG 組成の变化}

原肉および牛肉の NL の acyl chain の総炭素数に基 つく TG 組成ならびに加熱によるそれらの変化を Table 4 に示す。主な TG は, 両者共に C-48, C-50, C-52 およびC-54で，この5ちC-52の組成比が最も高かっ た。後述するよ5に，NL の構成脂肪酸の組成比は，豚 肉, 牛肉共に $\mathrm{C}_{18: 1}$ が約 $50 \%, \mathrm{C}_{16: 0}$ が $22 \sim 25 \%$ を占

Table 3 Changes in lipid class contents of non-polar lipid fractions in pork and beef during heat treatment at various $\mathrm{F}$ values $\left(124^{\circ} \mathrm{C}\right)$

$(\mathrm{mg} / 100 \mathrm{~g})$

\begin{tabular}{|c|c|c|c|c|c|c|c|}
\hline \multirow{2}{*}{ Sample } & \multirow{2}{*}{$\begin{array}{l}\text { Heat treatment } \\
\text { ( } F \text { value })\end{array}$} & \multicolumn{6}{|c|}{ Lipid class*1 $(\mathrm{mg} / 100 \mathrm{~g})$} \\
\hline & & $1,2-\mathrm{DG}$ & ST & $\mathrm{SE}+\mathrm{HC}$ & $1,3-\mathrm{DG}$ & FFA & TG \\
\hline \multirow[t]{4}{*}{ Pork (Ground) } & $\mathrm{R} * 2$ & 22.2 & 104.1 & - & - & 51.0 & 2163 \\
\hline & 8. 6 & 5.5 & 76.5 & $\operatorname{tr}$ & - & 22.3 & 2172 \\
\hline & 12 & 4.5 & 76.9 & $\operatorname{tr}$ & 1.6 & 18.3 & 2278 \\
\hline & 21 & 6.3 & 87.1 & $\operatorname{tr}$ & - & 22.1 & 2403 \\
\hline \multirow[t]{5}{*}{ Pork (Slice) } & $\mathrm{R}^{* 2}$ & 16.6 & 96.7 & $\operatorname{tr}$ & - & 85.9 & 3411 \\
\hline & 4. 6 & 2.7 & 57.2 & $\operatorname{tr}$ & - & 16.8 & 1333 \\
\hline & 7.9 & 6.8 & 89.0 & $\operatorname{tr}$ & - & 23.9 & 3826 \\
\hline & 21 & 1.9 & 81.7 & $\operatorname{tr}$ & 一 & 26.1 & 2281 \\
\hline & 32 & 8.0 & 171.7 & $\operatorname{tr}$ & 4.5 & 36.6 & 3269 \\
\hline \multirow[t]{4}{*}{ Beef (Ground) } & $\mathbf{R}^{* 2}$ & 36.8 & 77.8 & - & - & 109.5 & 7277 \\
\hline & 8. 6 & 21.9 & 88.4 & - & - & 93.1 & 7601 \\
\hline & 12 & 22.8 & 132.6 & $\cdots$ & $\cdots$ & 106.2 & 6863 \\
\hline & 21 & 25.2 & 136.9 & - & - & 98.4 & 7611 \\
\hline \multirow[t]{5}{*}{ Beef (Slice) } & $R^{* 2}$ & 35.6 & 151.8 & - & - & 144.3 & 9038 \\
\hline & 4.6 & 25.9 & 114.7 & - & - & 125.8 & 8984 \\
\hline & 7.9 & 24.0 & 111.1 & - & - & 105.8 & 8646 \\
\hline & 21 & 9.8 & 99.0 & - & 3.0 & 98.3 & 7351 \\
\hline & 32 & 28.1 & 189.6 & - & 114.6 & 123.0 & 10068 \\
\hline
\end{tabular}

\footnotetext{
*1 : 1, 2-DG; 1, 2-diglyceride, ST; cholesterol, SE+HC; sterol ester plus hydrocarbon, 1, 3-DG; 1, 3diglyceride, FFA; free fatty acid, TG; triglyceride

*2 : Prior to cooking
} 
Table 4 Changes in triglyceride compositions of non-polar lipid fractions in pork and beef on the basis of carbon number in acyl chain during heat treatments at various $F$ values $\left(124^{\circ} \mathrm{C}\right)$

(Area \%)

\begin{tabular}{|c|c|c|c|c|c|c|c|}
\hline \multirow{2}{*}{ Sample } & \multirow{2}{*}{$\begin{array}{l}\text { Heat treatment } \\
\quad(\mathrm{F} \text { value })\end{array}$} & \multicolumn{6}{|c|}{ Carbon number in acyl chain } \\
\hline & & 46 & 48 & 50 & 52 & 54 & 56 \\
\hline \multirow[t]{4}{*}{ Pork (Ground) } & $\mathrm{R}^{*}$ & - & 1.1 & 10.2 & 65.1 & 23.0 & 0.7 \\
\hline & 8.6 & - & 1.2 & 8.3 & 69.2 & 21.4 & - \\
\hline & 12 & - & 1.6 & 11.8 & 65.8 & 21.8 & - \\
\hline & 21 & 1.7 & 2.8 & 19.5 & 63.4 & 12.5 & - \\
\hline \multirow[t]{5}{*}{ Pork (Slice) } & $\mathrm{R}^{*}$ & - & 1.4 & 10.2 & 69.2 & 19.2 & - \\
\hline & 4.6 & - & 1.3 & 9.3 & 69.0 & 20.5 & - \\
\hline & 7.9 & - & 1.7 & 10.4 & 66.9 & 21.0 & - \\
\hline & 21 & - & 2.0 & 14.5 & 67.8 & 15.7 & - \\
\hline & 32 & - & 2.0 & 10.9 & 67.9 & 19.2 & - \\
\hline \multirow[t]{4}{*}{ Beef (Ground) } & $\mathrm{R}^{*}$ & - & 4.7 & 16.1 & 60.2 & 19.0 & $\operatorname{tr}$ \\
\hline & 8.6 & - & 4.5 & 14.1 & 62.1 & 19.4 & - \\
\hline & 12 & - & 4.7 & 16.0 & 61.6 & 17.6 & - \\
\hline & 21 & 1.6 & 9.5 & 25.6 & 57.3 & 6.1 & - \\
\hline \multirow[t]{5}{*}{ Beef (Slice) } & $\mathrm{R}^{*}$ & - & 5.2 & 15.8 & 60.6 & 18.4 & - \\
\hline & 4.6 & - & 5.4 & 13.9 & 63.0 & 17.6 & - \\
\hline & 7.9 & - & 5.3 & 15.9 & 62.4 & 16.4 & - \\
\hline & 21 & 1.6 & 7.9 & 23.1 & 58.3 & 9.0 & - \\
\hline & 32 & 2.0 & 8.4 & 24.2 & 56.9 & 8.5 & - \\
\hline
\end{tabular}

\footnotetext{
* Prior to cooking
}

めていること,および $\mathrm{C}_{20}$ 以上の脂肪酸が極めて少ない ことから，C-52 および C-54の TGの分子種は, それ ぞれ $\left(\mathrm{C}_{16}, 2 \times \mathrm{C}_{18} ; \mathrm{C}_{16}\right.$ の脂肪酸 1 分子と $\mathrm{C}_{18}$ の脂肪酸 2 分子からなる TG) 怙よび $\left(3 \times \mathrm{C}_{18}\right)$ が主体を成する のと思われる。和田ら”によれば，牛肉脂質の TG 組成 の主な組合せは $\left(\mathrm{C}_{16: 0}, 2 \times \mathrm{C}_{18: 1}, 33.2 \%\right),\left(\mathrm{C}_{16: 0}, \mathrm{C}_{18: 0}\right.$, $\left.\mathrm{C}_{18: 1,}, 8.1 \%\right),\left(\mathrm{C}_{18: 0}, 2 \times \mathrm{C}_{18: 1}, 10.1 \%\right)$ お。び $(3 \times$ $\mathrm{C}_{18: 1}, 9.1 \%$ ) であるとい5。本研究に招ける試料の TG の分子種組成もこれと汪同様であろらと思われ る。

豚肉乱よび牛肉の NL の TG 組成は共に F 值が 8.6 および 12 (切身肉では 4.6 および 7.9) までの加熱で は，在とんど变化が認められなかったが，F值が 21 ま たはそれ以上になるまで加熱したときには，C-52 およ び C-54の TG の組成比は減少し，C-48 および C-50 の組成比は增加した。Table 3 に示したように, 供試肉 が切身肉の場合には供試部位によってTG 含量は試料ご とに多少異なるが，挽き肉の場合にはほぼ同様である。

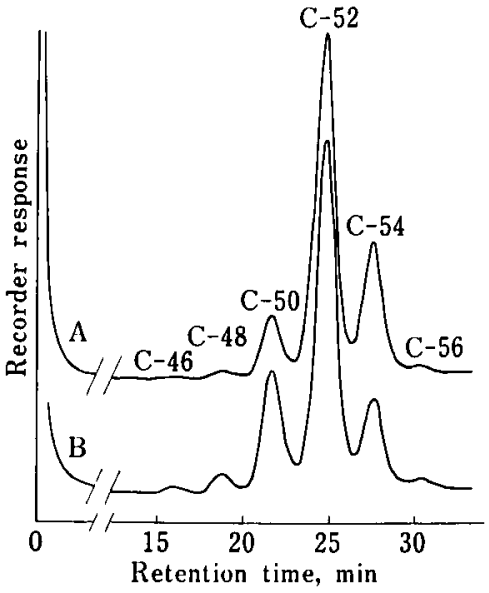

Fig. 2 Changes in gas chromatograms of triglycerides in non-polar lipid of pork during heat treatments at the $F$ values of 4.6 (A) and 21 (B) 
したがって，F 21 以上で加熱した豚肉および牛肉の C52 扰よびC-54の組成比の减少および C-48 和よびC50 の組成比の増加は，それらの TGの含有量の増減を 反映している。このよらな $\mathrm{TG}$ 組成の変化は, 䐂肉や牛 肉を F 21 以上で高温加熱したとき，TG が分子間また は分子内でェステル交換を起こしたことを示唆してい る。Fig. 2 には TG 組成の加熱による変化の一例とし て GLC ガスクロマトグラムを示した。

一般に，TGのェステル交換には著しい高温か，ある いは sodium methoxide のよ5な触媒の存在が必要で あるといわれている8)。比較的低い $124^{\circ} \mathrm{C}$ 加熱により TGのエステル交換が起こる理由は明らかでない。考亲 られることは肉成分中にェステル交換を促進する因子が 含まれているか，あるいは肉の高温加熱中に促進因子が 生成することなどであるが，この点については今後さら に検討したい。

5. 加熱に伴う TL, PL および NL の脂肪酸組成の 变化

TL，PL 扩よび NL の脂肪酸組成ならびにそれらの 加熱に伴ら変化をそれぞれ Table 5，6 扰よび 7 に示 す。TLの脂肪酸組成は, 豚肉も牛肉む相互に類似し,
$\mathrm{C}_{18: 1} ， \mathrm{C}_{16: 0}, \mathrm{C}_{18: 0}$ および $\mathrm{C}_{18: 2}$ が主な構成脂肪酸で, このうち $\mathrm{C}_{18: 1}$ の組成比が最も高かった。また，高度不 飽和脂肪酸として少量の $\mathrm{C}_{18: 3}$ および $\mathrm{C}_{20: 4}$ を含んでい た。しかし，これらの脂肪酸組成は，加熱に伴ってほと んど変化しなかった。NLの脂肪酸組成すTLのそれと ほほ同様で，また加熱による脂肪酸組成の変化も認めら れなかった。

豚肉の PL の脂肪酸組成は， $\mathrm{C}_{18: 2}$ の組成比が最も高 く,ついで $\mathrm{C}_{16: 0,}, \mathrm{C}_{18: 0}, \mathrm{C}_{18: 1}$ 打よび $\mathrm{C}_{20: 1}$ などが多か ったが, 一方牛肉の場合には, $\mathrm{C}_{18: 2}, \mathrm{C}_{18: 1}, \mathrm{C}_{16: 0}, \mathrm{C}_{18: 0}$ 和よび $\mathrm{C}_{20: 4}$ の順に組成比が高かった。一般に，NLに 此べて PL に高度不飽和脂肪酸の組成比が高かった。し かし，いずれの PL む加熱に伴う顕著な脂肪酸組成の変 化は認められなかった。

6. 加熱に伴う PC，PE および FFA の脂肪酸組成 の变化

PC の脂肪酸組成は, Table 8 に示すように PL の場 合と同様に $\mathrm{C}_{18: 2}, \mathrm{C}_{16: 0}, \mathrm{C}_{18: 1,}, \mathrm{C}_{18: 0}$ 扩よび $\mathrm{C}_{20: 4}$ が主 な脂肪酸であり，加熱による変化はほとんど認められな かった。

一方，PE の場合には Table 9 に示すように，加熱

Table 5 Changes in fatty acid compositions of the total lipids in pork and beef during heat treatments at various $\mathrm{F}$ values $\left(124^{\circ} \mathrm{C}\right)$

(Area \%)

\begin{tabular}{|c|c|c|c|c|c|c|c|c|c|c|c|c|c|c|c|c|c|c|}
\hline \multirow{3}{*}{$\mid \begin{array}{c}\text { Sample } \\
\text { valtye } \\
\text { acid } \\
\text { acidy }\end{array}$} & \multicolumn{9}{|c|}{ Pork } & \multicolumn{9}{|c|}{ Beef } \\
\hline & \multicolumn{4}{|c|}{ Ground } & \multicolumn{5}{|c|}{ Slice } & \multicolumn{4}{|c|}{ Ground } & \multicolumn{5}{|c|}{ Slice } \\
\hline & $\mathrm{R}^{*}$ & 8.6 & 12 & 21 & $\mathrm{R}^{*}$ & 4.6 & 7.9 & 21 & 32 & $\mathrm{R}^{*}$ & 8.6 & 12 & 21 & $\mathrm{R}^{*}$ & 4.6 & 7.9 & 21 & 32 \\
\hline $14: 0$ & 1.3 & 1.1 & 1.4 & 1.2 & 1.3 & 1.0 & 1.2 & 1.3 & 1.1 & 2.0 & 1.9 & 1.9 & 1.9 & 1.9 & 1.9 & 1.8 & 2.0 & 1. 1 \\
\hline $15: 0$ & 1.1 & 0.9 & 0.7 & 1.2 & 0.7 & 1.3 & 0.5 & 0.5 & 0.6 & 0.9 & 1.1 & 1.1 & 1.2 & 1.3 & 1.2 & 1.2 & 1.2 & 0.5 \\
\hline $16: 0$ & 22.8 & 21.3 & 22.9 & 22.3 & 23.2 & 20.8 & 22.2 & 23.0 & 22.6 & 26.8 & 24.2 & 24.7 & 24.2 & 24.8 & 24.2 & 24.2 & 25.5 & 23.0 \\
\hline$: 1$ & 3. 3 & 3.8 & 4.1 & 3.7 & 3.4 & 4. 0 & 3.4 & 3. 7 & 3.4 & 4.6 & 4.9 & 4.9 & 5.1 & 5.0 & 5.0 & 4.9 & 5.1 & 3.9 \\
\hline$: 2$ & - & - & - & - & - & - & - & - & - & 0.5 & 0.6 & 0.5 & 0.5 & 0.6 & 0.5 & 0.5 & 0.5 & - \\
\hline $17: 0$ & 0.4 & - & 一 & - & - & - & - & - & - & - & - & - & - & - & - & - & - & - \\
\hline $18: 0$ & 10.5 & 10.8 & 10.8 & 10.6 & 11.0 & 11.0 & 11.3 & 10.6 & 10.8 & 11.4 & 11.2 & 10.9 & 11.1 & 10.9 & 11.3 & 11.6 & 10.7 & 10.2 \\
\hline$: 1$ & 45.5 & 45.8 & 45.1 & 45.4 & 45.7 & 43.2 & 46.0 & 45.8 & 47.1 & 48.5 & 50.1 & 50.4 & 50.2 & 50.3 & 50.2 & 49.9 & 49.5 & 45.3 \\
\hline$: 2$ & 12.3 & 13.1 & 12.8 & 12.5 & 12.1 & 14.8 & 12.7 & 12.2 & 12.0 & 4. 3 & 4.7 & 4. 3 & 4.5 & 3.9 & 4.2 & 4.4 & 4.2 & 12.8 \\
\hline$: 3$ & 1.2 & 1.3 & 1.2 & 1.3 & 1.2 & 1.1 & 1.4 & 1.2 & 1.1 & 0.5 & 0.8 & 0.9 & 0.8 & 0.8 & 0.9 & 0.8 & 0.7 & 1.7 \\
\hline $20: 0$ & - & - & - & - & 0.1 & - & - & - & - & - & - & - & - & - & - & - & - & - \\
\hline$: 4$ & 1.7 & 1.8 & 1.0 & 1.8 & 1.4 & 2.8 & 1.3 & 1.8 & 1.3 & 0.4 & 0.6 & 0.5 & 0.6 & 0.5 & 0.6 & 0.6 & 0.5 & 1.6 \\
\hline Sat. & 36.1 & 34.1 & $0=0$ & 35.3 & 36.3 & 24 & 250 & 25 & 35.1 & 41.1 & 38.4 & 206 & 38.4 & 38.9 & 38.6 & 50. 0 & 39.4 & 34.8 \\
\hline Monoenoic & 48.8 & 49.6 & 49.2 & 49.1 & 49.1 & 47.2 & 49.4 & 49.5 & 50.5 & 53.1 & 55.0 & 55.3 & 55.3 & 55.3 & 55.2 & 54.8 & 54.6 & 49.2 \\
\hline Dienoic & 12.3 & 13. 1 & 12.8 & 12.5 & 12.1 & 14.8 & 12.7 & 12.2 & 12.0 & 4.9 & 5.3 & 4.8 & 5.0 & 4.5 & 4.7 & 4.9 & 4.7 & 12.8 \\
\hline Polyenoic & 2.9 & 3.1 & 2.2 & 3.1 & 2.6 & 3.9 & 2.7 & 3.0 & 2.4 & 0.9 & 1.4 & 1.4 & 1.4 & 1.3 & 1.5 & 1.4 & 1.2 & 3.3 \\
\hline
\end{tabular}

* Prior to cooking 
Table 6 Changes in fatty acid compositions of non-polar lipid fractions in pork and beef during heat treatments at various $\mathrm{F}$ values $\left(124^{\circ} \mathrm{C}\right)$

(Area \%)

\begin{tabular}{|c|c|c|c|c|c|c|c|c|c|c|c|c|c|c|c|c|c|c|}
\hline \multirow{3}{*}{$\begin{array}{l}\text { Sample } \\
\text { value } \\
\text { acity }\end{array}$} & \multicolumn{9}{|c|}{ Pork } & \multicolumn{9}{|c|}{ Beef } \\
\hline & \multicolumn{4}{|c|}{ Ground } & \multicolumn{5}{|c|}{ Slice } & \multicolumn{4}{|c|}{ Ground } & \multicolumn{5}{|c|}{ Slice } \\
\hline & $\mathrm{R}^{*}$ & 8.6 & 12 & 21 & $\mathbf{R}^{*}$ & 4.6 & 7.9 & 21 & 32 & $\mathrm{R}^{*}$ & 8.6 & 12 & 21 & $\mathrm{R}^{*}$ & 4.6 & 7.9 & 21 & 32 \\
\hline $14: 0$ & 1.4 & 1.3 & 1.4 & 1.6 & 1.3 & 1.4 & 1.3 & 1.5 & 1.6 & 1.9 & 2.1 & 2.1 & 2.1 & 1.9 & 2.0 & 1.9 & 2.1 & 2.6 \\
\hline $15: 0$ & - & 0.1 & - & 0.1 & 0.7 & 0.1 & 0.1 & - & - & 0.9 & 0.9 & 0.8 & 1.1 & 0.8 & 0.9 & 0.8 & 0.8 & 0.9 \\
\hline $16: 0$ & 23.7 & 22.3 & 23.7 & 23.0 & 23.7 & 22.7 & 22.5 & 23.8 & 25.5 & 25.0 & 25.1 & 25.5 & 24.9 & 25.0 & 24.9 & 25.1 & 26.4 & 28.7 \\
\hline$: 1$ & 3.7 & 3.7 & 3.8 & 4.4 & 3.3 & 4.0 & 3.5 & 3.9 & 3.9 & 5.0 & 5.1 & . 4.9 & 5.1 & 4.8 & 5.0 & 4.8 & 4.8 & 5.2 \\
\hline$: 2$ & 0.2 & - & - & - & - & - & - & 一 & 0.3 & 0.6 & 0.5 & 0.5 & 0.5 & 0.6 & 0.5 & 0.6 & 0.5 & 0.3 \\
\hline $18: 0$ & 10.1 & 10.3 & 9.3 & 10.1 & 10.7 & 10.1 & 10.6 & 10.4 & 9.8 & 10.4 & 11.0 & 10.7 & 10.8 & 11.0 & 11.3 & 11.7 & 10.7 & 9.4 \\
\hline$: 1$ & 50.3 & 51.1 & 51.7 & 48.3 & 45.9 & 52.0 & 49.3 & 50.1 & 48.7 & 52.0 & 51.3 & 51.7 & 51.5 & 52.0 & 51.1 & 50.8 & 50.9 & 49.5 \\
\hline$: 2$ & 8.7 & 9.2 & 8. 7 & 10.2 & 12.0 & 7.9 & 10.7 & 8.7 & 8.6 & 3.2 & 3.3 & 3.3 & 3.2 & 3.2 & 3.4 & 3.4 & 3.2 & 2.9 \\
\hline$: 3$ & 1.4 & 1.4 & 1.3 & 1.9 & 1.2 & 1.3 & 1.5 & 1.3 & 1.2 & 0.8 & 0.7 & 0.7 & 0.8 & 0.7 & 0.8 & 0.8 & 0.7 & 0.5 \\
\hline $20: 0$ & 0.1 & - & - & - & - & 0.1 & - & 0.2 & 0.2 & - & - & - & - & - & - & - & - & - \\
\hline$: 4$ & 0.4 & 0.4 & - & 0.5 & 1.3 & 0.5 & 0.4 & 0.1 & 0.2 & 0.1 & 0.1 & 一 & 0.1 & 0.1 & 0.1 & 0.1 & - & 0.1 \\
\hline at. & 35.3 & 54.0 & 04.4 & 34.8 & 36.4 & 04.4 & & & 37.1 & 38.2 & & & 38.9 & 38.7 & 39.1 & 09.0 & 40.0 & 41.0 \\
\hline Monoenoic & 54.0 & 54.8 & 55.5 & 52.7 & 49.2 & 56.0 & 52.8 & 54.0 & 52.6 & 52.0 & 56.4 & 56.6 & 56.6 & 56.8 & 56.1 & 55.6 & 55.7 & 54.7 \\
\hline Dienoic & 8.9 & 9.2 & 8.7 & 10.2 & 12.0 & 7.9 & 10.7 & 8.7 & 8.9 & 3.8 & 3.8 & 3.8 & 3.7 & 3.8 & 3.9 & 4.0 & 3.7 & 3.2 \\
\hline Polyenoic & 1.8 & 1.8 & 1.3 & 2.4 & 2.5 & 1.8 & 1.9 & 1.4 & 1.4 & 0.9 & 0.8 & 0.7 & 0.9 & 0.8 & 0.9 & 0.9 & 0.7 & 0.6 \\
\hline
\end{tabular}

* Prior to cooking

Table 7 Changes in fatty acid compositions of polar lipid fractions in pork and beef during heat treatments at various $\mathrm{F}$ values $\left(124^{\circ} \mathrm{C}\right)$

(Area \%)

\begin{tabular}{|c|c|c|c|c|c|c|c|c|c|c|c|c|c|c|c|c|c|c|}
\hline \multirow{3}{*}{\multicolumn{2}{|c|}{$\begin{array}{l}\text { Sample } \\
\text { value } \\
\text { Fatty } \\
\text { acid }\end{array}$}} & \multicolumn{8}{|c|}{ Pork } & \multicolumn{9}{|c|}{ Beef } \\
\hline & & \multicolumn{3}{|c|}{ Ground } & \multicolumn{5}{|c|}{ Slice } & \multicolumn{4}{|c|}{ Ground } & \multicolumn{5}{|c|}{ Slice } \\
\hline & & 8.6 & 12 & 21 & $\mathrm{R}^{*}$ & 4.6 & 7.9 & 21 & 32 & $\mathbf{R}^{*}$ & 8.6 & 12 & 21 & $\mathrm{R}^{*}$ & 4.6 & 7.9 & 21 & 32 \\
\hline $14: 0$ & 0.3 & & 0.1 & 0.2 & & 0.2 & 0.2 & 0.2 & 0.2 & 0.8 & 0.4 & 0.7 & 0.3 & 0.7 & 0.6 & 0.4 & 0.4 & 0.3 \\
\hline $16: 0$ & 18. 6 & 16.9 & 22.7 & 21.0 & 19.1 & 18. 1 & 18.2 & 21.0 & 22.1 & 16.7 & 17.0 & 19.4 & 14.3 & 17.0 & 17.1 & 17.4 & 16.0 & 14.6 \\
\hline$: 1$ & 0.1 & 1.2 & 0.1 & 1.1 & 0.9 & 1.2 & 1.1 & 1.2 & 1.4 & 1.5 & 1.6 & 2.2 & 1.8 & 1.3 & 1.7 & 1.7 & 1.9 & 1.7 \\
\hline 18:0 & 18. 1 & 15.8 & 15.8 & 14.8 & 15.5 & 15.6 & 16.4 & 15.9 & 13.4 & 16.6 & 16.5 & 18.0 & 15.6 & 15.0 & 17.1 & 18.0 & & 15.0 \\
\hline$: 1$ & 15.9 & 15.6 & 15.5 & 15.4 & 15.2 & 15.5 & 15.7 & 15.5 & 14.9 & 24.0 & 23.0 & 21.9 & 22.5 & 23.4 & 23.8 & 22.3 & 24.9 & 22.0 \\
\hline$: 2$ & 34.5 & 35.2 & 33.6 & 34.3 & 36.5 & 37.0 & 36.3 & 34.8 & 37.8 & 27.9 & 27.7 & 23.4 & 29.6 & 27.0 & 28.0 & 26.0 & 28.5 & 29.1 \\
\hline$: 3$ & 0.6 & 0.6 & 0.6 & 0.6 & 0.6 & 0.6 & 0.5 & 0.7 & 0.5 & 0.8 & 0.8 & 1.0 & 1.0 & 0.8 & 0.8 & 0.9 & 0.9 & 1.0 \\
\hline $20: 0$ & - & - & - & - & 0.2 & 0.1 & 0.1 & 0.4 & 0.1 & 0.1 & - & - & 0.3 & 0.1 & - & $\div$ & - & 0.1 \\
\hline$: 4$ & 10.2 & 11.6 & 9.3 & 10.2 & 10.0 & 9.7 & 9.5 & 9.3 & 8.7 & 9.6 & 10.4 & 8.8 & 11.5 & 12.4 & 9.1 & 10.1 & 10.3 & 13.0 \\
\hline$: 5$ & 0.7 & 1.7 & 0.6 & 0.8 & 0.5 & 0.6 & 0.7 & 0.6 & 0.5 & 0.4 & 0.3 & 0.8 & 1.1 & 0.5 & 0.2 & 0.2 & 0.3 & 1.3 \\
\hline $22: 4$ & 1.1 & 1.1 & 1.7 & 1.4 & 1.3 & 1.2 & 1.3 & 0.4 & 0.4 & 1.5 & 2.3 & 3.7 & 1.9 & 1.6 & 1.5 & 2.9 & 1.4 & 1.8 \\
\hline
\end{tabular}

Sat.

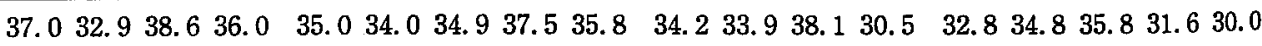

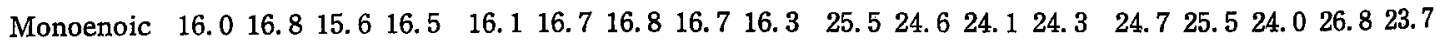
Dienoic $34.535 .233 .6 \quad 34.3 \quad 36.537 .036 .334 .837 .8$ $27.927 .723 .429 .6 \quad 27.028 .026 .028 .529 .1$

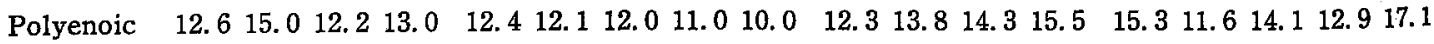


Table 8 Changes in fatty acid compositions of phosphatidylcholine of pork and beef during heat treatments at various $\mathrm{F}$ values $\left(124^{\circ} \mathrm{C}\right)$

\begin{tabular}{|c|c|c|c|c|c|c|c|c|c|c|c|c|c|c|c|c|c|c|}
\hline \multirow{3}{*}{$\begin{array}{c}\text { Sample } \\
\text { value } \\
\text { Fatty } \\
\text { acid }\end{array}$} & \multicolumn{9}{|c|}{ Pork } & \multicolumn{9}{|c|}{ Beef } \\
\hline & \multicolumn{4}{|c|}{ Ground } & \multicolumn{5}{|c|}{ Slice } & \multicolumn{4}{|c|}{ Ground } & \multicolumn{5}{|c|}{ Slice } \\
\hline & $\mathrm{R}^{*}$ & 8.6 & 12 & 21 & $\mathbf{R}^{*}$ & 4.6 & 7.9 & 21 & 32 & R* & 8.6 & 12 & 21 & $\mathrm{R}^{*}$ & 4.6 & 7.9 & 21 & 32 \\
\hline $14: 0$ & 0.6 & 0.2 & 0.2 & 0.3 & 0.6 & 0.2 & 0.2 & 0.2 & 0.4 & 0.5 & 0.3 & 0.6 & 0.3 & $\operatorname{tr}$ & 0.5 & 0.6 & 0.6 & 0. \\
\hline $16: 0$ & 27.2 & 30.0 & 33.2 & 37.1 & 37.2 & 31.0 & 31.9 & 30.6 & 35.5 & 29.2 & 25.9 & 25.8 & 33.3 & 27.1 & 26.2 & 25.6 & 26.1 & 27.1 \\
\hline$: 1$ & 1.6 & 0.1 & 0.1 & 0.1 & 1.3 & 0.1 & 0.1 & 0.1 & 1.2 & 1.4 & 2.0 & 2.4 & 1.7 & 1.6 & 2.0 & 2.2 & 2.1 & \\
\hline 18:0 & 5.7 & 7.5 & 7.2 & 9.4 & 8.3 & 7.2 & 8.0 & 7.0 & 8.1 & 6.4 & 8.0 & 7.3 & 9.0 & 5.1 & 7.2 & 7.5 & 7.5 & \\
\hline$: 1$ & 27.4 & 18.7 & 18.4 & 15.8 & 16.1 & 18.8 & 18.0 & 17.9 & 14.7 & 25.9 & 28.1 & 29.7 & 22.9 & 25.7 & 27.9 & 29.7 & 28.2 & 24 . \\
\hline$: 2$ & 27.9 & 37.8 & 36.0 & 29.7 & 29.7 & 37.5 & 36.3 & 38.5 & 31.7 & 25.8 & 27.6 & 25.7 & 24.0 & 31.0 & 28.3 & 27.0 & 26.9 & 28.7 \\
\hline$: 3$ & 0.9 & 0.5 & 0.5 & 0.6 & 1.0 & 0.6 & 0.4 & 0.4 & 1.1 & 1.0 & 0.7 & 1.0 & 1.0 & 1.0 & 0.8 & 0.8 & 0.7 & \\
\hline 20:0 & 0.1 & 0.1 & - & 0.2 & 0.2 & - & - & - & 0.4 & 1 & - & - & 0.3 & 0.2 & 0.2 & - & - & \\
\hline$: 4$ & 6.7 & 4.4 & 3.8 & 5.0 & 3.9 & 4.0 & 4.0 & 4.6 & 5.2 & 7.0 & 6.4 & 5.8 & 6.0 & 7.7 & 5.8 & 5.7 & 6.9 & \\
\hline$: 5$ & 0.2 & 0.3 & 0.2 & 0.5 & 0.3 & 0.1 & 0.3 & 0.3 & 1.0 & 0.9 & 0.1 & 0.7 & 0.3 & - & 0.2 & 0.2 & 0.2 & \\
\hline $22: 4$ & 1.6 & 0.4 & 0.3 & 1.4 & 1.4 & 0.4 & 0.7 & 0.4 & 0.6 & 1.6 & 0.8 & 0.8 & 1.3 & 0.6 & 0.9 & 0.8 & 0.8 & \\
\hline & & & & & & & & & & & & & & & & & & 30. \\
\hline onoenoic & 29.0 & 18.8 & 18.5 & 15.9 & 17.4 & 18.9 & 18.1 & 18.0 & 15.9 & 27.3 & 30.1 & 32.1 & 24.6 & 27.3 & 29.9 & 31.9 & 30.3 & 26. \\
\hline enoic & 27.9 & 37.8 & 36.0 & 29.7 & 29.7 & 37.5 & 36.3 & 38.5 & 31.7 & 25.8 & 27.6 & 25.7 & 24.0 & 31.0 & 28.3 & 27.0 & 26.9 & 28.7 \\
\hline olyenoic & 9.4 & 5.6 & 4.8 & 7.4 & 6.6 & 5.1 & 5.4 & 5.7 & 7.9 & 10.6 & 8.0 & 8.3 & 8.6 & 9.3 & 7.7 & 7.5 & 8.6 & 9.8 \\
\hline
\end{tabular}

* Prior to cooking

Table 9 Changes in fatty acid compositions of phosphatidylethanolamine of pork and beef during heat treatments at various $\mathrm{F}$ values $\left(124^{\circ} \mathrm{C}\right)$

\begin{tabular}{|c|c|c|c|c|c|c|c|c|c|c|c|c|c|c|c|c|c|c|}
\hline \multirow{3}{*}{$\begin{array}{l}\text { Sample } \\
\text { value } \\
\text { acid }\end{array}$} & \multicolumn{9}{|c|}{ Pork } & \multicolumn{9}{|c|}{ Beef } \\
\hline & \multicolumn{4}{|c|}{ Ground } & \multicolumn{5}{|c|}{ Slice } & \multicolumn{4}{|c|}{ Ground } & \multicolumn{5}{|c|}{ Slice } \\
\hline & $\mathbf{R}^{*}$ & 8.6 & 12 & 21 & $\mathrm{R}^{*}$ & 4. 6 & 7.9 & 21 & 32 & $\mathbf{R}^{*}$ & 8.6 & 12 & 21 & $\mathrm{R}^{*}$ & 4.6 & 7.9 & 12 & 21 \\
\hline $14: 0$ & 0.5 & 0.1 & 0.1 & 0.1 & 1.5 & 0.1 & 0.1 & 0.1 & 0.2 & 0.4 & 0.3 & 0.1 & 0.1 & 0.5 & 0.2 & 0.2 & 0.1 & 0.1 \\
\hline $16: 0$ & 3.6 & 6.3 & 3.9 & 6.5 & 4.9 & 4.1 & 4.2 & 3.0 & 4.2 & 5.3 & 5.8 & 5.2 & 6.5 & 4.2 & 3.3 & 4.6 & 2.4 & 3.3 \\
\hline$: 1$ & 0.4 & 0.6 & 0.6 & 0.5 & 0.2 & 0.6 & 0.7 & 0.6 & 0.4 & 0.5 & 1.3 & 1.2 & 0.9 & 0.4 & 0.6 & 1.0 & 0.8 & 0.6 \\
\hline $18: 0$ & 28.1 & 25.0 & 26.7 & 30.2 & 33.2 & 25.6 & 25.8 & 25.9 & 32.1 & 29.4 & 28.6 & 30.2 & 34.8 & 27.9 & 34.9 & 29.5 & 27.4 & 29.6 \\
\hline$: 1$ & 8.7 & 11.3 & 10.6 & 10.5 & 7.4 & 10.8 & 11.3 & 9.0 & 10.0 & 13.6 & 15.0 & 14.1 & 14.5 & 10.0 & 13.4 & 15.5 & & 12.4 \\
\hline$: 2$ & 29.4 & 35.5 & 35.3 & 25.4 & 21.0 & 37.0 & 35.2 & 37.6 & 28.2 & 22.8 & 26.6 & 26.7 & 23.2 & 23.7 & 22.1 & 25.8 & 28.3 & 24.4 \\
\hline$: 3$ & 1.6 & 0.5 & 1.3 & 2.0 & 2.7 & 0.5 & 1.2 & 1.2 & 1.6 & 1.2 & 0.6 & 0.7 & 1.0 & 0.5 & 0.7 & 1.0 & 0.9 & 0.9 \\
\hline $20: 4$ & 21.3 & 17.8 & 17.3 & 16.2 & 18.3 & 18.2 & 17.2 & 17.7 & 21.4 & 20.5 & 18. 2 & 17.2 & 14.8 & 28.8 & 15.5 & 17.7 & 21.2 & 22.1 \\
\hline$: 5$ & 1.4 & 1.1 & 0.9 & 1.2 & 1.2 & 1.3 & 1.1 & 1.1 & 1.6 & 1.2 & 0.8 & 0.4 & 0.3 & 1.1 & 0.5 & 0.5 & 0.6 & 0.9 \\
\hline $22: 4$ & 4.9 & 1.8 & 3.3 & 7.4 & 9.6 & 1.8 & 3.0 & 3.7 & 0.3 & 5.1 & 2.7 & 4.0 & 3.9 & 2.9 & 8. 6 & 4.1 & 4.8 & 5.6 \\
\hline Nal. & 32.2 & & & 36.8 & 39.6 & 29.8 & 30.1 & 29.0 & 36.5 & 35.1 & 34.8 & & 41.4 & 32.6 & 00.4 & 04.0 & 20.0 & 00.0 \\
\hline Monoenoic & 9.1 & 11.9 & 11.2 & 11.0 & 7.6 & 11.4 & 12.0 & 9.6 & 10.4 & 14.1 & 16.3 & 15.3 & 15.4 & 10.4 & 14.0 & 16.5 & 14.3 & 13. 0 \\
\hline Dienoic & 29.4 & 35.5 & 35.3 & 25.4 & 21.0 & 37.0 & 35.2 & 37.6 & 28.2 & 23.8 & 26.6 & 26.7 & 23.2 & 23.7 & 22.1 & 25.8 & 28.3 & 24.4 \\
\hline Polyenoic & 29.2 & 21.2 & 22.8 & 26.8 & 31.8 & 21.8 & 22.5 & 23.7 & 24.9 & 27.0 & 22.3 & 22.3 & 20.0 & 33.3 & 25.3 & 23.3 & 27.5 & 29.5 \\
\hline
\end{tabular}

* Prior to cooking 
Table 10 Changes in fatty acid compositions of free fatty acid fractions of pork and beef during heat treatments at various $\mathrm{F}$ values $\left(124^{\circ} \mathrm{C}\right)$

(Area \%)

\begin{tabular}{|c|c|c|c|c|c|c|c|c|c|c|c|c|c|c|c|c|c|c|}
\hline \multirow{3}{*}{$\begin{array}{l}\text { Sample } \\
\text { value } \\
\text { Fatty } \\
\text { acid }\end{array}$} & \multicolumn{9}{|c|}{ Pork } & \multicolumn{9}{|c|}{ Beef } \\
\hline & \multicolumn{4}{|c|}{ Ground } & \multicolumn{5}{|c|}{ Slice } & \multicolumn{4}{|c|}{ Ground } & \multicolumn{5}{|c|}{ Slice } \\
\hline & $\mathrm{R}^{*}$ & 8.6 & 12 & 21 & $\mathrm{R} *$ & 4.6 & 7.9 & 21 & 32 & $\mathrm{R}^{*}$ & 8.6 & 12 & 21 & $\mathrm{R}^{*}$ & 4.6 & 7.9 & 21 & 32 \\
\hline $14: 0$ & 4.6 & 2.9 & 4.4 & & & 3.9 & & 1.5 & & & 3.1 & 1.5 & 2.2 & 4.0 & 3.6 & 2.9 & 1.3 & 1.5 \\
\hline $15: 0$ & 6.1 & & 1.7 & & & 1.3 & & 0.6 & & & 1.9 & 0.6 & 1.2 & 0.9 & 2.0 & 1.4 & 0.3 & 0.8 \\
\hline $16: 0$ & 29.7 & 25. 2 & 25.5 & 34.1 & 23.1 & 34.3 & 26.7 & 29.3 & 28.6 & 41.3 & 29.8 & 29. 7 & 34.4 & 29.2 & 32.3 & 26.8 & 384 & 31.8 \\
\hline$: 1$ & & 5.2 & 6.7 & 3.8 & & 5.0 & 5.6 & 4.1 & 4.0 & 3.7 & 5.5 & 4.0 & 5.8 & 4.8 & 6.1 & 5.1 & 3.7 & 4.9 \\
\hline$: 2$ & 0 & 0.4 & 0.7 & - & 1.1 & - & - & 0.3 & 0.1 & 0.5 & - & 0.2 & - & 0.7 & - & - & 0.2 & 0.2 \\
\hline $17: 0$ & 0.8 & - & - & - & - & - & - & - & - & - & - & - & - & - & - & - & - & - \\
\hline $18: 0$ & & 11.8 & 11.6 & 14.9 & 8.6 & 14.9 & 11.0 & 13.5 & 12.7 & & 13.3 & 12.5 & 12.5 & 9.4 & 13.3 & 10.4 & 14.5 & 8.5 \\
\hline$: 1$ & 24.7 & 30.2 & 28.6 & 25.9 & 30.9 & 21.9 & 31.1 & 26.2 & 29.2 & & 26.7 & 30.3 & 26.0 & 30.4 & 24.8 & 29.4 & 24.8 & 28.2 \\
\hline$: 2$ & 19.0 & 17.9 & 16.7 & 14.9 & 16.7 & 14.9 & 15.5 & 19.0 & 18.3 & 10.9 & 14.7 & 16.5 & 13.4 & 16.5 & 13.8 & 17.7 & 13.2 & 17.1 \\
\hline$: 3$ & - & 0.9 & 0.8 & 0.7 & 1.2 & 0.9 & 1.2 & 1.1 & 1.2 & - & 0.8 & 0.7 & 0.5 & 0.5 & 0.5 & 0.8 & - & 1.2 \\
\hline $20: 0$ & 0.1 & 0.1 & - & - & 0.5 & - & - & 0.2 & 0.2 & 0.4 & 0.5 & - & 0.1 & - & - & - & - & - \\
\hline$: 4$ & 1.1 & 3.7 & 3.3 & 2.9 & 2.0 & 3. 0 & 3. 0 & 4.2 & 3.8 & 2.2 & 3. 6 & 4.2 & 3.9 & 3. 6 & 3.7 & 5.7 & 3.6 & 5.6 \\
\hline
\end{tabular}

Sat.

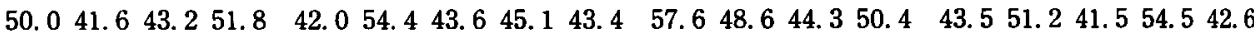
Monoenoic $29.6 \quad 35.435 .2 \quad 29.7 \quad 37.026 .936 .7 \quad 30.3 \quad 33.2 \quad 28.932 .2 \quad 34.3 \quad 31.8 \quad 35.2 \quad 30.934 .528 .633 .1$ $\begin{array}{llllllllllllllllllllllll}\text { Dienoic } & 19.3 & 18.3 & 17.4 & 14.9 & 17.8 & 14.9 & 15.5 & 19.3 & 18.4 & 11.4 & 14.7 & 16.7 & 13.4 & 17.2 & 13.8 & 17.7 & 13.4 & 17.3\end{array}$

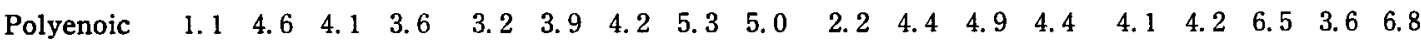

* Prior to cooking

によって脂肪酸組成に変化が認められた。すず，䐁肉で む牛肉でも生鮮肉の $\mathrm{PE}$ の脂肪酸組成には, $\mathrm{C}_{18: 2}, \mathrm{C}_{18: 0}$ および $\mathrm{C}_{20: 4}$ の組成比が高く, 全体の $70 \%$ 以上を占め ていた。しかし, 加熱肉の脂肪酸組成では, 泺切身肉を 除くと $\mathrm{C}_{20: 4}$ の組成比が明らかに低かった。その他の脂 肪酸の組成比には一定の変化は認められなかった。

IGENE ら9) も牛肉および鷄肉をレトルトパウチに詰め て真空包装して, 中心温度が $70^{\circ} \mathrm{C}$ になるまで加熱した ときの脂質の変化を調べているか，PCより PEの方が 不安定であったと述べている。このはか鷄肉防について も同様な観察がなされている。

加熱による PEの $\mathrm{C}_{20: 4}$ の組成此の減少については, 酵素的加水分解，加熱に上る加水分解または熱分解ある いは酸化などの原因が考えられるが，Table 2 に示した ように加熱により LPE が増加していること， $\mathrm{C}_{20: 4}$ のよ うな高度不䬷和脂肪酸はPLの $\beta$ 位に結合している比率

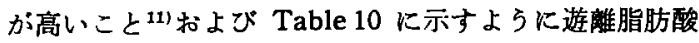
中 $\mathrm{C}_{20: 4}$ の組成比が加熱により增加していることなどを 考え併せると，すでにリゾ型リン脂質の増加に関連して 諭じたように, 少なくとも $\mathrm{PE} 中 の \mathrm{C}_{20: 4}$ の一部は phospholipase $\mathrm{A}_{2}$ の作用により減少したものと思われる。
勿論，前述の他の原因む無視できないことはいうまでる ない。

加熱に伴亏遊離脂肪酸組成の変化は，Table 10 に示 すように，極めて複雑で解析が图難であった。その理由 は FFA が NLや PL から酵素的加水分解または加熱 による加水分解などによって生成する一方，酸化や熱分 解などによって減少するためと思われる。 $\mathrm{C}_{20: 4}$ を除い て，一定の变化を示した脂肪酸は諗められなかった。

$$
\text { 要 約 }
$$

豚肉，牛肉の切身肉拉よび挽き肉をレトルトパウチ に真空包装して, 高温加熱処理（中心温度 $124^{\circ} \mathrm{C}, \mathrm{F}$ 值 4. 6〜32 の範囲) をしたときの脂質成分の変化を調へ， 次のような結果を得た。

（1）加熱に伴う全脂質含量および水分ははとんど変化 しなかったが，極性脂質区がやや增加した。

（2）加熱により豚肉の TBA 値は上昇したか，F值の 上昇に伴って TBA 値が增加するといら傾向はみられな かった。一方，牛肉の TBA 值は加熱により減少した。

（3）加熱により豚肉，牛肉共にリゾ型りン脂質が增加 したが，遊離脂肪酸はむしろ減少傾向を示した。 
(4) F 值が 21 以上になるよらに加熱すると，原肉， 牛肉共に acyl chain に基うく triglyceride 組成が变化 した。このことから，加熱中に分子内あるいは分子間で エステル交換が起こったものと推定した。

（5）各脂質区の脂肪酸組成は，加熱によりほとんど変 化しなかったが, phosphatidylethanolamine の $\mathrm{C}_{20: 4}$ は明らかに減少した。

終りに，本研究を行うに当たり御協力を賜わった東京 水座大学須山教授ならびに䃊，木村両助教授に感謝する。 文献

1) Pearson, A. M., Love, J. D. and Sholand, F. B.: Adv. Food Res., 23, 1 (1977).

2) Allen, C.E. and Allen, E. F.: Food Technol., 35, 253 (1981).
3) BLIGH, E. G. and Dyer, W. J.: Can. J. Biochem. Physiol., 37, 913 (1959).

4) Tipton, C. L., Paulis, J. W. and Pierson, M. D.: J. Chromatog., 14, 486 (1964).

5) Sinnhuber, R. O. and YU, T. C.: Yukagaku, 26, 259 (1977).

6) Keller, J.D. and Kinsella, J. E.: J. Food Sci., 38, 1200 (1973).

7) Wada, S., Kolzumi, C., Takiguchi, A. and NonaKA, J.: Yukagaku, 27, 579 (1978).

8)松井宜也：油化学, 28, 680 (1979).

9) Igene, J. O. and Pearson, A. M.: J. Am. Oil Chemists' Soc., 44, 1285 (1979).

10) Lee, W. T. and Dawson, L. E.: J. Food Sci., 38, 1232 (1973).

11) Kuchmak, M. and Dugan, L. R. JR.: J. Am. Oil Chemists' Soc., 42, 45 (1965).

(昭和 59 年 9 月 29 日受理) 